\title{
Maintaining Systems in Language News are Criminal in Mass Media
}

\author{
L Syafyahya \\ Andalas University, Limau Manis Padang \\ \{lenisy@hum.unand.ac.id\}
}

\begin{abstract}
News languages in the mass media sometimes describe a criminal act openly by mentioning who the perpetrators and victims are and often the news disguises who is guilty and who is the victim. This paper aims to explain the system of naming and aspects of meaning in the news language of crime in the mass media. The method used in data collection, namely the referral method and proficient method. The data analysis method used is the equivalent method and the method of religion. At the analysis stage, data is also carried out, namely editing and coding. Based on analysis.in rape cases, generally the naming given with more touching words is more emotional to the audience than the naming given to the murder victim. This was done to show the impartiality of the news writer and to invite the audience to side with the victim. Disguising the identity of the victims is also one of the signs of concern felt by news writers and also to maintain calm for the victims and their relatives. Then, the perpetrators of crimes are also placed in a position that must be fully responsible for the crimes they have committed. In a murder case, naming is emphasized to the perpetrator of the crime. The choice of words used in naming shows the perpetrator's cruelty. The identity of the victim and the perpetrator of the crime is clearly explained and the relationship between the victim and the perpetrator of the crime is also described. Words that are used as naming in crime news have aspects of meaning, sense of 'understanding', feeling 'feeling', tone 'tone', and intension 'goal'. These four aspects of meaning strongly support the determination of the naming system and provide affective stimulation to the reader, so that the reader gets complete information.
\end{abstract}

Keywords: Language, Action News, Criminal

\section{INTRODUCTION}

The language of the news in the mass media sometimes describes a criminal act openly by stating who the perpetrator of the crime is and who the victim must get sympathy. However, often the news also proclaims the crime by disguising who is guilty and who is the victim. This can be seen, for example in news of crimes in the mass media, both printed and electronic. The language talks about crime in print media are found in the writings of Djatmika [1]. In the article, Djatmika reviewed the language of criminal acts with the approach of stylistics and transitivity. He took data from The Jakarta Post newspaper and concluded that for rape texts, news writers put themselves in a position to side with the victims differently from other types of crime. The transitivity system is more specifically about the material clauses that are engineered 
in the article. It appears that there are actors as perpetrators of crime and goals as victims of crime.

In this paper, the author speaks the language of criminal acts in print and television media with a semantic approach, especially the naming problem and the meaning aspects contained in the language of crime. Semantics is a system and investigation of meanings and meanings in a language or language in general [2]. EncyBritanica 1965 says semantics is the study of a language differentiator with the relationship of mental processes or symbolism in speech activities [2]. Language studies are basically cultural events, through human language designating their world. This world is full of names given by humans. Humans not only give names, but also give meaning, even they are also given a name and meaning. [1] Giving names in a text is an effective way to convey information, because the names given usually contain certain meanings in it.

Kridalaksana stated that naming is the process of finding language symbols to describe objects, concepts, and processes, usually by utilizing existing treasuries [3]. The naming relationship between one word and its reference object is most clearly seen in the name of self, a case of the naming paradigm. [4]. A name can function as a term, the terms will become clear if given a definition as well as the name.

Talking about meaning as a liaison between the language and the outside world in accordance with the agreement of the community users so that they understand each other The meaning has three levels of existence namely, 1) meaning becomes the content of a form of language, 2) meaning becomes the content of a language, and 3) meaning becomes the content of communication that is able to produce certain information [2]. At the first and second levels, viewed in terms of its relationship with speakers, while the third level emphasizes the meaning in communication. The use of news in criminal acts is included in the third level, which is emphasized in the meaning in communication. On the other hand, Palmer said that in analyzing meaning in communication there are four aspects of meaning that can be considered through Indonesian language data [2]. The four aspects are, sense of 'understanding', feeling 'feeling', tone 'tone', and intension 'goal'.

\subsection{Research Method}

Problem solving is the end to be achieved in one study. For this reason, it is necessary to establish regular work steps. Step order is a very meaningful effort for the continuity and success of a study. There are three stages of strategy in solving research problems, namely: 1) the stage of providing data, 2) the stage of data analysis, and 3) the stage of presenting the results of data analysis [5]. This is also in accordance with the opinion of Moleong [6] and Subroto [7].

Provision of criminal language news language data the author obtained from written sources. Furthermore, the data obtained by various methods and techniques are used together to complement each other. As a first step, by observing the target object of the research the author uses the introspection method. The next step, the referral method and the interview method are used. This referral method is used by tapping. In addition to the recording, recording can also be done on the data card and after that the data is analyzed.

Capable methods can be compared with the interview method. The author's skillful method uses to get a description of the responses of viewers of legal proceedings to the use of the crime language's news language. This skillful method in its implementation is assisted by fishing techniques as basic techniques and proficient techniques as advanced techniques. In analyzing crime language news language data, distributional methods are used. The reason for choosing a 
distributional method is because the news language is a crime using the language determination tool itself.

The distributional method uses the defining tools of the language itself. The technique used in this method is called the direct element technique as a basic technique and advanced technique, namely substitution technique (substitution). The stage of presenting the results of the analysis is done in two ways, namely the formal method and the informal method. Formal method using signs and symbols. The intended sign includes a plus sign (+), a hyphen (-), and an arrow ( $\square$ ). The informal method is formulation with words.

\subsection{Results and Discussion}

Pattipeiloly F. [8]. conducted research on the effect of news on criminal acts against the vigilance of Samarinda housewives. He said the criminal news exposure presented by the newspaper sapos had an influence on the level of alertness of housewives. The more the level of intensity of housewives reading criminal acts the higher the alertness of housewives [8]. Andrianis conducts research on criminal news on television and satisfaction gaps in descriptive gap studies and satisfaction watching criminal crime news $\{\mathrm{RCTI}\}$ and Buser $\{\mathrm{SCTV})$ among students of Faculty of Law. Law of Univ. Eleven March [9]. He said the respondents experienced a gap between expected satisfaction and satisfaction gained in watching ambush and buser criminal news programs [9].

Previously, LeniSyafyahya had also conducted research on the crime language news on SCTV. The results of his research explain how the authors favor the victims of crime [10]. In this study, data was obtained from mass media. Mass media as a means of communication functions as a teacher who conveys social heritage, carers who present information and interpretations of various events, as discussion forums, and as sources of entertainment [11]. The choice of words in the mass media greatly affects the reader. The use of word accuracy is influenced by language skills related to the ability to know, understand, master, and use a number of vocabulary actively which can express ideas correctly so that they can communicate effectively to the reader or listener [12].

From the analysis, naming systems and aspects of meaning in the language of criminal acts can be distinguished based on several things, namely: types of criminal acts, victims of criminal acts, and criminals. In this paper, the differences in the naming system in the crime of rape and the criminal acts of murder against the victim and the perpetrators can be seen in the following tables;

\begin{tabular}{|c|c|c|c|}
\hline $\begin{array}{l}\text { Establishment of } \\
\text { Vocational Victims }\end{array}$ & $\begin{array}{l}\text { Maintainment } \\
\text { on victims of Murder }\end{array}$ & $\begin{array}{l}\text { Establishment } \\
\text { of Roses }\end{array}$ & $\begin{array}{l}\text { Maintainment } \\
\text { on Killing People }\end{array}$ \\
\hline $\begin{array}{l}\text { Girl Under Age } \\
\text { (Mawar) } \\
\text { Student of middle } \\
\text { school } \\
\text { Underage girls } \\
\text { Self name } \\
\text { Victim }\end{array}$ & $\begin{array}{l}\text { Small Girl From Eight } \\
\text { Years } \\
\text { (Alvina) } \\
\text { self name } \\
\text { pronominal } \\
\text { smart kid } \\
\text { victim }\end{array}$ & $\begin{array}{l}\text { Girl Under The } \\
\text { Age } \\
\text { young man } \\
\text { suspects } \\
\text { self name } \\
\text { student }\end{array}$ & $\begin{array}{l}\text { Small Girl From Eight } \\
\text { Years } \\
\text { (Alvina) } \\
\text { Parents } \\
\text { the waife } \\
\text { his wife } \\
\text { pronominal }\end{array}$ \\
\hline $\begin{array}{l}\text { Young mother } \\
\text { (Puspa) } \\
\text { TKW }\end{array}$ & $\begin{array}{l}\text { About Wife Husbands } \\
\text { (Sulaiman And } \\
\text { Sutarmi) }\end{array}$ & $\begin{array}{l}\text { Youth Mosquito } \\
\text { People } \\
\text { Man }\end{array}$ & $\begin{array}{l}\text { About Wife Husbands } \\
\text { (Sulaiman And Sutarmi) } \\
\text { suspects }\end{array}$ \\
\hline
\end{tabular}




\begin{tabular}{llll} 
& self name & & \\
- & Pronominal & suspects & a man \\
Selfname & $\begin{array}{l}\text { a couple of husband } \\
\text { and wife } \\
\text { Victim }\end{array}$ & $\begin{array}{l}\text { self name } \\
\text { thugs }\end{array}$ & self name \\
Victim & & & \\
\hline
\end{tabular}

From table establishment of vocational victims and table maintainment on victims of murder above, it can be seen that the naming system given to victims of crime is underage girls more than the naming system for victims of adult crime. This is done by news writers to attract sympathy and a deeper sense of compassion from the readers to the victims. The naming of underage girls is more emphasized by including the age of the victim, the achievement of the victim and the relationship between the victim and the perpetrator of the crime. In the news, it can be assumed that the news writer tries to convince and lead the minds of he readers to an opinion that the perpetrators of crimes are very deserving of punishment according to the violence and cruelty they have committed.

In addition, the naming given to young mothers emphasizes the work of the victim. Addition of information about the area of origin of the victim and the status of the victim who has had a child and the age of the victim is carried out to attract sympathy and compassion for the listeners.

As with the naming system given to a husband and wife, the emphasis is on the victim's own name. In addition, there is a naming of one of the victims with an old man, here the news writer influences the reader / audience how cruel the perpetrator is. Because the old man mentioned, is in a weak condition (sick) and not powerless.

The names given to rape victims will be different from the names given to victims of murder. In rape victims, the name given is a pseudonym, whereas in the murder victim it is not. This is done by the news writer with the aim of protecting the victim. In other words, here there is a partiality of the news writer for rape victims. The partiality of the news writer for the victim can also be seen from the disguise of the residence of the rape victims. This disguise was carried out so that the victims did not increaseembarrassed and not more burdened by reporting events to themselves to the community.

In addition to naming victims of crime, certain perpetrators of the crime are also given names. In tables establishment of roses and maintainment on killing people, it can be seen that the naming system is given to rape and murder of minors more than rape and murder of adults. In the case of rape, the names given to the perpetrator are related to the status of the perpetrator, for example, students, minors, while in the case of murder the naming of the perpetrator is more emphasized in the relationship between the victim and the perpetrator, for example; mother, mother. Naming is done to give the reader an idea of the cause of the murder.

Giving names to each event / event, fact, and process in a text is an effective way to convey information, because the names given usually contain certain meanings in it. There are four aspects of meaning that can be considered in a crime language event.

First, the meaning aspect of the meaning is also called a theme that involves the idea / message in question. Information that is told / reported has a core problem which is usually referred to as a theme. The core issue reported in the Mawar and Puspa cases is the issue of rape, whereas in the case of Alvina and a husband and wife are issues of murder

Second, the meaning of feelings related to the speaker's attitude and the speaker's situation. Aspects of feeling are born with a choice of words that are in accordance with the situation. In the event of rape and murder above, you can see several words that contain aspects of the 
meaning of feeling. Words that contain feeling aspects of meaning will be grouped into two parts, namely;

\subsection{Rape Case}

\subsubsection{The torn Rose case}

A. Words that contain aspects of the meaning of feelings intended for the victim, including: (a) painful, (b) suffering, (c) injuries on the part of his genitals and the shock of the soul, (d) trauma that is very heartbreaking, B. Words that contain aspects of meaning intended for the perpetrator of the crime, including: (a) accursed, (b) young, (c) depraved, (d) submitting. The tainted Puspa case A. Words that contain aspects of the feelings intended for the victim, including: (a) suffering, (b) disaster, (c) trauma, (d) danger. B. Words that contain aspects of feeling intended for the perpetrator of the crime, including: (a) vile deeds, and (b thugs)

\subsubsection{Homicides}

Cases of murder against Alvina, including: A. Words that contain aspects of feelings intended for the victim; (a) stretched, (b) claimed life, (c) died, (d) memories, B. Words that contain aspects of the meaning of feelings intended for the perpetrator of the crime, including: (a) finish off, (b) take away, (c) become a demon, (d) not normal, 2.2 Cases of murder of Sulaiman and Sutarmi, A. Words that contain aspects of the feelings intended for the victim, including: (a) mysteries killed, (b) covered in blood, (c) very tragic, (d) trivial, B. Words that contain aspects of feeling intended for the perpetrator of the crime, including: (a) slaughter, (b) grandson of 20 people and 8 great-grandchildren, (c) cleanse, (d) obstruct his love.

In the case of rape, it can be seen that there are some differences in the use of words that indicate aspects of the meaning of feelings. This difference is caused by different situations. The situation in the Mawar case is rape committed against children. Rape committed against children can result in the future destruction of the child, compared to the rape committed against women who have families.

Rape that is committed against adult women / women who have a family can also be caused because the woman gives the opportunity / opportunity to the perpetrators.In murder cases, it can be seen that there are some differences in the use of words that indicate aspects of the meaning of feelings. This difference is also caused by differences in situations. The situation in Alvina's case is the murder committed against biological children. The words used to show the meaning of feelings to children are more in touching the feelings of the reader / audience than the words that indicate aspects of the meaning of feelings towards the murder of Sulaiman and Sutarmi (a husband and wife).

The words used to show the meaning aspects of feeling on the murder of a husband and wife are more emphasized in the cruelty and cruelty of the perpetrator, menunsukan. The difference in the use of words that contain aspects of feelings can also be seen from the title of a news. In the case of rape, the news writer gives a title based on the suffering borne by the victim, for example; "Torn roses" and "tainted Puspa". If seen from the meaning of the word; torn 'something that has been damaged and difficult to repair 'and stains' something that has been traced', the news writer gave information to the audience how terrible the impact of rape on children. In addition, in the murder case the title is based on the background of the murder. The planned murder was clearly described the tool used to kill "scissors" and explained how the perpetrator strategically eliminated his traces, while in unplanned murder more focused on the 
psychological condition of the perpetrator both before the murder occurred and after the murder occurred.

The difference in the use of words that express the meaning aspects of feelings is also intended for the perpetrators of crime. The use of a word that states the meaning of the aspect of feeling for the perpetrators of rape crimes and the killing of minors provokes emotion, creates hatred, and rages the readers towards the perpetrators. Even the perpetrator of the crime is likened to an animal, for example, Initially Mawar was raped by a suspect Hafid. After Hafid ventured his animal appetite, it was Fandi's turn to enter the room as before, and Mawar was raped again.

Third, the aspect of tone / tone is related to the tone of the language used. This aspect of the meaning of the tone is also related to the meaning aspects of feeling. Fourth, the aspect of the purpose of the goal relates to the goals to be expressed. What is expressed in the meaning of the aspect of the goal has a specific purpose, for example by saying that the animal's desire is for the listener to know the appetite of an offender as well as the desire of an animal. Aspects of this purpose involve 6 classifications of statements that are: declarative, persuasive, imperative, political, and pedagogical.

Of the six classifications of the statement, in cases of rape and murder, they generally contain narrative aspects of purpose. Besides narrative aspects of meaning, there are also some aspects of persuasive and declarative meanings. The language used by the event's author is generally declarative and persuasive [13].

\section{CONCLUSIONS}

Based on the analysis conducted on the language of criminal acts, we can see the strategies used by news writers in expressing their ideology in providing naming to both the victims of crime and the perpetrators of the crime. In addition, news writers also express their ideology by considering aspects of meaning in language.

In the case of rape, generally the naming given with more touching words provokes the audience more than the naming given to the murder victim. This is done to show the impartiality of the news writer and invite the reader to take sides with the victim. Disguising the identity of the victims is also one sign of concern felt by news writers and also to maintain security for victims and their relatives. Then, the perpetrators of crime, are also placed in a position that must be fully responsible for the crimes they have committed. In a murder case, naming is emphasized to the perpetrator of the crime. The choice of words used in naming shows the perpetrator's cruelty. In addition, the identity of the victim and the perpetrator of the crime is clearly explained and the relationship between the victim and the perpetrator of the crime is also described.

Words that are used as naming in crime news have aspects of meaning, sense of 'understanding', feeling 'feeling', tone 'tone', and intension 'goal'. These four aspects of meaning strongly support the determination of the naming system and provide affective stimulation to the reader, so that the reader gets complete information.

\section{REFERENCES}

[1] Djatmika, "Bahasa Tindak Kriminal: Pendekatan Stilistika dengan Sistem Penamaan dan Transitivity tentang Posisi Wanita sebagai Korban Kejahatan". Linguistik Indonesia," Linguist. Indones., 2004.

[2] F. Djadjasudarma, Semantik I. Bandung: Eresco, 1993. 
[3] H. Kridalaksana, Kamus Linguistik. Jakarta: Gramedia, 1993.

[4] A. (penerj. ). Wahab, Teori Semantik. Surabaya: Airlangga University Press., 1995.

[5] Sudaryanto, Metode dan Aneka Teknik Analisis Bahasa. Yogyakarta: Duta Wacana University Press., 1993.

[6] L. J. Moleong, Metodologi Penelitian Kualitatif. Bandung: Remaja Rosdakarya., 1990.

[7] D. E. Subroto, Pengantar Metode Penelitian Linguistik Struktural. Ed. 1. Surakarta: Sebelas Maret University Press., 1992.

[8] P. F., "PengaruhTerpaan Berita Kriminal Terhadap Kewaspadaan Ibu RT Samarinda (Studi Kasus Harian Samarinda Pos di Kelurahan Teluk Lerong Ulu RT 10 Samarinda," ilkom, 2013.

[9] Andriastuti, "Berita Kriminal di Televisi dan Kesenjangan Kepuasan (Studi Deskriptif Kesenjangan Kepuasan Menonton Berita Kriminal Sergap (RCTI) dan Buser (SCTV) di Kalangan Mahasiswa Fak. Hukum Unive. Sebelas Maret,” 2009.

[10] L. Syafyahya, "“ Bahasa berita Tindak Kriminal dalam Acara Derap Hukum di SCTV'.," Padang, 2004.

[11] W. at. al. Rivers, Media Massa dan Masyarakat Modern. Jakarta: Prenada Media, 2003.

[12] H. Widjono, Bahasa Indonesia: Mata Kuliah Pengembangan Kepribadian di Perguruan Tinggi. Jakarta: Grasindo, 2005.

[13] K. Saddhono, "Language and superdiversity: Indonesians knowledging at home and abroad. By Zane Goebel." Soc. Stu. vol. 12 no.1 pp. 113-118, 2018 